This article was downloaded by: [Elsa Lechner]

On: 27 May 2014, At: 08:25

Publisher: Routledge

Informa Ltd Registered in England and Wales Registered Number: 1072954 Registered

office: Mortimer House, 37-41 Mortimer Street, London W1T 3J H, UK

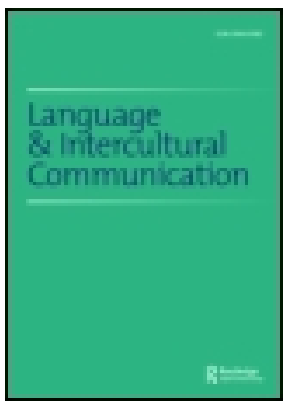

\title{
Language and Intercultural Communication
}

Publication details, including instructions for authors and subscription information:

http:// www.tandfonline.com/loi/ rmli20

\section{The migrant patient, the doctor and the (im)possibility of intercultural communication: silences, silencing and non-dialogue in an ethnographic context}

\author{
Elsa Lechner ${ }^{a} \&$ Olga Solovova ${ }^{b}$ \\ a Center for Social Studies, University of Coimbra, Coimbra, \\ Portugal \\ ${ }^{\mathrm{b}}$ Centre for Social Studies, Coimbra, Portugal \\ Published online: 23 May 2014.
}

To cite this article: Elsa Lechner \& Olga Solovova (2014): The migrant patient, the doctor and the (im)possibility of intercultural communication: silences, silencing and nondialogue in an ethnographic context, Language and Intercultural Communication, DOI: 10.1080/ 14708477.2014.914727

To link to this article: http:// dx.doi.org/ 10.1080/ 14708477.2014.914727

\section{PLEASE SCROLL DOWN FOR ARTICLE}

Taylor \& Francis makes every effort to ensure the accuracy of all the information (the "Content") contained in the publications on our platform. However, Taylor \& Francis, our agents, and our licensors make no representations or warranties whatsoever as to the accuracy, completeness, or suitability for any purpose of the Content. Any opinions and views expressed in this publication are the opinions and views of the authors, and are not the views of or endorsed by Taylor \& Francis. The accuracy of the Content should not be relied upon and should be independently verified with primary sources of information. Taylor and Francis shall not be liable for any losses, actions, claims, proceedings, demands, costs, expenses, damages, and other liabilities whatsoever or howsoever caused arising directly or indirectly in connection with, in relation to or arising out of the use of the Content.

This article may be used for research, teaching, and private study purposes. Any substantial or systematic reproduction, redistribution, reselling, Ioan, sub-licensing, systematic supply, or distribution in any form to anyone is expressly forbidden. Terms \& 
Conditions of access and use can be found at http://www.tandfonline.com/page/termsand-conditions 


\title{
The migrant patient, the doctor and the (im)possibility of intercultural communication: silences, silencing and non-dialogue in an ethnographic context
}

\author{
Elsa Lechner ${ }^{\mathrm{a} *}$ and Olga Solovova ${ }^{\mathrm{b}}$ \\ ${ }^{a}$ Center for Social Studies, University of Coimbra, Coimbra, Portugal; ${ }^{b}$ Centre for Social Studies, \\ Coimbra, Portugal
}

\begin{abstract}
This paper attempts to reflect on the impossibilities of intercultural communication implied in institutional medical encounters. Drawing from an ethnographic case study among patients of a transcultural consultation for migrants in Portugal, the analysis focuses on the contents and forms of the interaction observed by the anthropologist in the clinical setting. A repetitive pattern of communication between a refugee women patient and her psychiatrist foregrounded the unsaid within the interaction as well as the unwillingness of the refugee to speak about her life with the anthropologist. In this sense, we propose to understand silence as a form of communication pointing to both the condition of the patient but more significantly embedded in the institutional framework of the clinical setting, discursive positions of the participants, as well as their social statuses. Following the theoretical work of Jaworski, Wagner and Winter, our analysis of silence leads us to the critical examination of the question of privilege in intercultural situations pointing to a necessary deconstruction of post-colonial institutional object/subject positions. In practical terms, this challenge corresponds to the work of international cross-cultural psychiatry (in terms of clinical matters) as well as that of biographical research and research on memory among migrants and refugees.
\end{abstract}

Este texto propõe uma reflexão sobre comunicação intercultural num contexto institucional comprometedor da sua possibilidade efectiva. Partindo de um caso ocorrido no trabalho de campo na consulta do migrante num hospital psiquiátrico em Lisboa, é feita uma análise sobre as formas e conteúdos da comunicação entre os interlocutores envolvidos: paciente refugiada, médico e antropóloga. Tanto o caracter repetitivo da comunicação entre médico e paciente, como a recusa da refugiada em contar a sua história à antropóloga, trazem para o centro da análise a questão do silêncio que é aqui entendido como uma forma de comunicação substantiva. Neste sentido são aqui analisados também o peso institucional do contexto nas posições discursivas possíveis bem como o peso dos estatutos sociais dos diversos intervenientes. Seguindo o trabalho teórico de Jarowski, Wagner e Winter, a nossa reflexão sobre o silêncio conduziu-nos a uma análise crítica da questão do privilégio nas relações interculturais indicando uma necessária desconstrução da 'dominação incorporada' nas nossas próprias posições de sujeito (médicos e cientistas sociais face a migrantes e refugiados). $\mathrm{O}$ trabalho da nova psiquiatria cultural, apelidada de internacional, traduz-se nisso mesmo na prática clínica, bem como o trabalho da pesquisa biográfica junto de migrantes e refugiados.

*Corresponding author. Email: elsalechner@ces.uc.pt 
Keywords: communication; silence; asymmetries; new cross-cultural psychiatry; biographical research

History is the privilege that we should remember so as not to forget ourselves.

(Michel De Certeau)

Encounters between migrants and public institutions in the host countries enact structural asymmetries within the very communicational contexts of interaction (Delory-Momberger, 2012; Giordano, 2008; Laacher, 2007; Portes, 2011). In such contexts, language and intercultural communication often slip into silences permeated by significant historical meaning which have been thoroughly addressed in scientific literature (anthropology, linguistics, cultural psychiatry and subaltern studies) film (documentary and fiction) and literary studies (comparative literature and feminist theories). Drawing from an ethnographic work in a migrant consultation at a psychiatric hospital in Portugal, this paper reflects upon the various analytical dimensions of silences and silencing in contexts marked by asymmetries between the interlocutors. Inspired by Jaworski's work, we consider it more productive to view silence not as the opposition to speech, but rather see both silence and speech as integral parts of communication (Jaworski, 1993). Silence is here understood as the non-enunciation of subjectivity before prevalent forms of power. However, we are interested in uncovering the symbolic potential this silence may imply. In our particular research these forms of power are embodied in the relations between doctors and migrant patients in clinical settings, between men and women, and between researchers and the researched. All the above reflect the larger structural inequalities that involve migrants, citizens and institutional experts.

Similarly to Roy Wagner, we focus our analysis on silences as forms of embodied action ('performatives', Wagner, 2012, p. 2) that may raise profound questions about the historical circumstances underlying the unequal relations between subjects and forms of knowledge in situations of inequality. In this sense, the unuttered or confiscated discourse of migrants can serve as a catalyst for the acceptance of the ambivalences and contradictions of institutional interculturality as a way to try to go beyond it. A further practical proposition is made by advocating biographical research as the relational kind of research.

\section{Fernanda's silences or the monologue of hegemonic knowledge}

The case study presented here is based on Lechner's fieldwork in the 'Transcultural Psychiatry Consultations ${ }^{1}$, at the Miguel Bombarda Hospital in Lisbon, carried out between July 2004 and December $2007 .^{2}$ The project involved research in the domain of the psychopathology of migrations, medical anthropology and cultural psychiatry, situated in the Portuguese institutional context. Having been granted formal permission by the outpatients' administrative board and the hospital's ethics committee to do the ethnographic work at the migrant consultation (Consulta do Migrante), it consisted in: presence during the consultations between psychiatrists/psychotherapists and migrants; participation in team meetings; direct contact with the patients; individual interviews with the practitioners and patients. Research was focused on the migration and clinical backgrounds of the patients, their reasons for attending these consultations. Lechner was looking into the discourses of pain and resilience that could potentially be uttered, 
announced or revealed in the patient-doctor and patient-anthropologist relationship (Lechner, 2009).

This particular case study concerned a woman in her sixties (Fernanda will be a fictional name), who was attending weekly consultations with one of the psychiatrists of the 'transcultural group'. Fernanda lived in a reception centre for refugees, from where she had been referred to the hospital. The country she arrived from (not her country of origin, Cabo Verde) had been at war when she left (at gunpoint, she said), so she had been brought to Portugal by the Portuguese army. She had several children, each living in a different country, including the USA, Italy and Portugal. Before the refugee centre, Fernanda had lived in one of her daughters' houses in the outskirts of Lisbon but tensions between them subsequently resulted in the cease of communication.

The refugee centre administration had referred Fernanda to the specialist consultations because she had alleged feeling tired and confused while unable to establish good relations with the other refugees at the centre. Besides this, her legal status and accommodation needed to be taken care of, since Fernanda had no passport nor valid personal documentation.

Over the course of weeks and months, Fernanda, the psychiatrist and the anthropologist had met in the hospital, and every time, the interaction would follow a similar route. The doctor would ask Fernanda about her medication routines, about the legalisation progress and about the contacts with her son. Fernanda would repeat practically the same answers over and over again. Over the months, both the patient and the doctor seemed to have settled into a repetitive pattern of interaction. Given the therapeutic objective of the interaction, the unspoken may have been of more interest to the doctor yet he seemed to overlook it. In fact, in Lechner's anthropological view Fernanda's silence meant a lot, despite being influenced by the doctor's authority that clearly shaped, in its turn, what and how could or could not be said by Fernanda.

Despite Fernanda's consultations apparently going nowhere, she insisted on coming to talk to the doctor either to get the medication or for a break in her daily routine. At least nothing specific in her narrative of a woman who had migrated between various African countries and tried to settle as a refugee in Portugal could point to a possible explanation.

The psychiatrist had already arrived at Fernanda's diagnosis: he described it as a 'psychotic' state. The best treatment, in his opinion, relied on keeping the edifice of Fernanda's life intact, since any questioning might have unbalanced her fragile state. Lechner learned about this upon resuming Fernanda's consultation observation after a brief absence: Fernanda hugged and kissed the returning researcher with a broad smile, clearly pleased to see her back in the room. After Fernanda had left, the doctor observed: 'She hugged you. That sort of relationship with the body is not usual in a person who suffers with psychosis'.

It may appear that the doctor was questioning his own diagnosis. Yet that was not the case. He kept his diagnosis and continued to medicate the patient accordingly. One might also ask whether the doctor was opening his evaluation to discussion. But that was not the case, either. The doctor never questioned his diagnosis and went through Fernanda's behaviour without any change of position or transformation of ideas. There was no dialogue between the unquestioned knowledge of the doctor and Fernanda's manifest behaviour in loco, neither was there any medical discussion on the evidence of the indicated diagnostic feature. In our view, it is precisely this non-dialogue that may help understand Fernanda's repetitions and silences in that setting. As an outsider doing fieldwork in the hospital, Lechner was not meant to intervene, make comments or decide 
what to do. So, it led to a necessarily silent and 'neutral' position for the anthropologist position in that particular setting.

Prior to the described event of the psychiatric diagnosis and evaluation, Fernanda had been asked by the researcher to concede to an interview outside the hospital. She replied that her story was 'too sad', and that she did not want to talk about it. In this sense, her silence was not only replicated at the consultations with the doctor in the hospital, but also in her relationship with the anthropologist inside and outside that institution.

Such facts bring forth the question of the privilege of discursive positions of the psychiatrist and the anthropologist as compared to Fernanda's (refugee). The therapeutic setting represented an institutional space laden with power asymmetries which shaped the actions, words and practices of every person within it. Having been originally referred to the transcultural psychiatry consultation by the refugee centre, Fernanda was seen, spoken to and interacted as a patient, a foreigner, a low-qualified migrant refugee and a nonnative speaker of Portuguese. In contrast, both the psychiatrist and anthropologist were seen, spoken to and interacted as educated Portuguese nationals, institutional actors of the host society and native speakers of Portuguese. Compared to the anthropologist's and the patient's, the psychiatrist's position within the setting was even further reinforced/ legitimated by his alleged authority as a medical expert and the institutional licence to enact it as Fernanda's doctor. Besides this, the gender roles within the setting had to be acknowledged. Such a constellation of asymmetries had resulted in a very restricted space for Fernanda's communication; resulted in an 'abyss' requiring a post-abyssal thinking and post-colonial epistemology to bridge such great differences (Bhabha, 1983; Spivak, 1988; Sousa Santos, 2007). Differences deeply rooted in the privilege of 'the doctors' against the total disadvantage of the refugee patient.

In his thinking about the concept of privilege and how it is internalised by dominant groups, Bob Pease (2006) understands it as the other side of oppression. Following the work of feminist theory and critical reflection in human services (mostly social work but equally applicable to clinical work or social research), Pease indicates two ways of dealing with privilege in work positions and social life: (1) focusing solely on oppression and the oppressed or (2) by paying attention also to the domination contexts and dominant groups. In the first case, there is the 'reinforcement of the structure of invisibility of privilege' (Bailey, 1998, p. 17, apud), allowing the complex systems of domination to rely on the oppression to generate their privilege. The advantages and benefits of the privileged ones result from their membership in dominant groups with access to multiple kinds of resources (material, symbolic, intellectual and political), as well as institutional power.

In the second case - that of becoming aware of one's own privilege - there is a necessary deconstruction of self-incorporated social dominance. The author explains:

people live their lives trying to attain certain valued aspirations associated with these statuses. Thus, rather than seeing the concepts of race, gender and class as reified categories, we should be more interested in the process of gendering, racialising and classing. (Pease, 2006, p. 17)

Critically exploring the concept of privilege, the author goes on to identify its key characteristics: not recognised by its protagonists, unconscious, naturalised and structuring the world through invisible mechanisms. On the contrary, oppression is directly recognised by those who suffer it, experienced in the body and soul and lived as a violence that does harm rather than mobilizes. For these reasons, privileged groups have 
become the model of the norm ('normative human relations'), that is, hegemony in person. This applies to social conduct, interpersonal behaviour, communication and intercultural communication. Even though privilege may be partial or relative, it functions as domination through its points of location (social class, gender and race) and its processes of reproduction (communication and non-reflexive acts). Internalised domination is the core challenge for critical reflection and social justice, since it blocks effective validation of the 'others'.

The way out from this invisible mechanism of domination, therefore, can be found in the emancipation of the privileged groups, along with that (old struggled) emancipation of the oppressed and subordinated. To address the potential for members of privilege groups to develop a critical distance from their privilege, Pease turns to feminist theory (Harding, 1995) and subaltern studies: if profeminist men can challenge patriarchal power, antiracist whites can challenge white privilege. In the same way, we can state that anticolonial Europeans can challenge European privilege, and white men practising human service can challenge white male institutional service, as white men doctors can challenge white men's medicine, like doctors tout court can challenge their inherited positions of power and knowledge. From the monologue of their self-convinced unquestionable knowledge, doctors can move forward towards a critical reflection and action aware of history and politics. That is what international psychiatry is about.

On the other hand, the silent position of the non-privileged might be interpreted as a form of resistance. In his work 'The weapons of the weak: everyday forms of peasant resistance', the anthropologist James Scott refers to silence as the most significant and effective form of peasant resistance (Scott, 1985, p. xvi). Much of the same view, adds Scott, is appropriate to the study of slavery in the New World. In our case study, silences not only reflected the constraints of the institutional discursive framework (refugee centre and the therapeutic setting) but may have also included projections of the long-acting colonial discourses, which positioned Portuguese nationals (the doctor and the anthropologist) and nationals of former Portuguese colonies in Africa (the patient). Silences reflected the hegemonies (white, European, scientific and medical) weighing upon someone in Fernanda's position, as did her personal life experiences and her traditional African culture, along with her female condition. Ashcroft et al. affirm, in this regard, that 'The "silencing" of the post-colonial voice to which most recent theory alludes is in many cases a metaphoric rather than a literal one' (Ashcroft, Griffiths, \& Tiffin, 1995, p. 4). Besides this, Fernanda's silence underlines the materiality of the human body, which is vulnerable with its fears and desires (Lemke, 2008).

Cases like Fernanda's reflect the 'incommunicability' between the citizen and the foreigner, a documented person and one without papers, a migrant and a native, a refugee in a reception centre and a doctor in a state hospital, an illiterate and a representative of hegemonic knowledge. This 'incommunicability' results from the symbolic weight of all those discursive positions; Fernanda's identity had been 'objectified' - as Wagner (2012, p. 12) explains, it would 'not depend on responding to interpellation in given discursive situations'.

Even though Fernanda's account of fleeing the war-struck country 'at gunpoint' would suggest being subjected to torture, traumatic and painful experiences which may have led to such verbal 'incommunicability' (Caruth, 1996; Scarry, 1985), Lechner has no direct data about it. Fernanda never mentioned such topics, nor had the psychiatrist asked her about them. So the silence on these issues appears to be co-constructed. As mentioned above, the psychiatrist was explicit about the need not to ask too much. Fernanda seemed to be playing along. By going through the motions while leaving the 
traumatic experiences unstirred, Fernanda was performing her patient identity within the immediate therapeutic encounter. In a larger context, her silence provides her with a mechanism of suspending herself in the vulnerable position of a patient in need of medical attention. As long as the refugee centre institutional frameworks could afford to bring Fernanda to the psychiatrist, her unbroken silence may have entitled her to more medical visits to Lisbon.

Being part of communication (Jaworski, 1993), silence communicates meaning, which constitutes a social and dialogical accomplishment (Ashcroft et al., 1995). Hence we need to examine the silence of all the participants of the described therapeutic setting: the patient's, the psychiatrist's and the anthropologist's. Even though the reasons for these respective silences may be partly assigned to the respective discursive positions, it has been created by the interaction setting itself and the non-reflexive attitude adopted by the interlocutor in power.

Intercultural communication may be deemed possible when institutional actors assume and work from the symbolic asymmetries (an important part of cultural psychiatry work). This is called 'cultural competence' in psychiatry and requires the interdisciplinary dialogue between medical and social sciences and the humanities. Rather than essentialising the cultural identity of the patient and 'leaving it unstirred', Aschroft urges for a focus on cultural difference, which is discursively constructed and is always situated. In our case, the difference to be explored lies between Fernanda and the psychiatrist, between Fernanda and the anthropologist and between the psychiatrist and the anthropologist.

\section{Possible dialogues: deconstruction of incorporated dominance and the work of 'international psychiatry'}

The history of cultural psychiatry, in itself, is a history of interdisciplinary reflexion and practice (Kleinman, 1980, 1985, 1995; Kirmayer, 2000, 2001; Littlewood, 2006; Rousseau, 2002), as well as a critique of the modern Western science and societies (Beneduce, 1998; Barker \& Stevenson, 2000; Comelles, 2013; Fanon, 1952, 1961; Fernando, 2003; Littlewood, 1990). Doctors, anthropologists and philosophers, driven to the understanding of human behaviour and communication in cultural contexts, include their own professional activities and scientific knowledge in their situated inquiries, very much in the previously indicated movement of critical reflection and 'liberatory knowledge' mentioned by Pease (2006).

One of the features of cultural competence is contextual and historical depth of analysis. In this sense, silences can be understood as more than only a symptom of possible personal trauma. The very context of (non)encounter between a patient and a doctor is to be analysed in its plural dimensions for the sake of an accurate diagnosis: the encounter per se (motivations, institutional setting and subject positions) and the nonencounter in amount (repetitions, incommunicability and silences). Individual symptoms, as well as cultural languages of pain and resilience, are to be contextualised in the larger frame of institutional encounters. Thus, a culturally competent work enacts both the ethical and political dimensions of health care. By this enactment, the therapeutic relationship ends the 'colonialist appropriation of the word of the other' (Pandolfo, 1997) thus initiating a project of less formal interaction, understanding and communication. It invites dialogue and relational work. In the same direction, Bahktin (1981) suggested the concept of 'voice' to talk about the relational self, situated in space and time. 
Much literature in cultural psychiatry has addressed the 'micro politics' of therapeutic relations and health care. In Finland, a network-based language approach to psychiatric care, termed Open Dialogue, has been pioneered at Keropudas Hospital in western Lapland. Seikkula and Olson (2003) reporting on the approach worked as members of the original team. Recent studies suggest that this model has improved the therapy of people suffering from first-episode psychosis by significantly reducing frequent hospitalisation, the relapse rate and the use of medication (Seikkula et al., 2003). This approach has gained widespread recognition in Northern Europe where Seikkula, together with Norwegian psychiatrist Tom Andersen, has fostered an international network of teams using open dialogue and reflective processes in acute-care settings in Russia, Latvia, Lithuania, Estonia, Sweden, Finland and Norway. Open Dialogue method integrates a bigger collaborative therapy trend that started in the 1970s (Andersen, 2007). Collaborative therapy is developed by a worldwide community of practitioners and scholars committed to humanise mental care.

Among migrant patients and asylum seekers in long-term immigration countries like the USA, Canada, the UK or France, transcultural psychiatry has been particularly aware of the political and historical ingredients of the therapeutic encounters. The work of Cécile Rousseau in Montreal, Marie-Rose Moro in Paris or Sumann Fernando and Shushrut Jadhav in London are good examples of that. A detailed analysis of such practices could lead us to an interesting discussion on the influence of cultural acknowledgement into creative therapeutic strategies such as collective consultations, interdisciplinary teams, use of indigenous concepts, art therapy, ethno medicine and cartoons (Jadhav, 2009; Moro, 2005; Rousseau et al., 2006). Such choices engage a counter hegemonic movement of transformation of doctor/patient relationships and scientific knowledge within the medical psychiatric practice and academia. All of the mentioned practitioners are also professors and editors in the fields of medical anthropology, ethno psychiatry and cross-cultural and international psychiatry. Their clinical practice is critically reflected in and by their academic endeavours. In its turn, the latter are informed by the former.

In this sense, a transcultural practitioner would reflect on Fernanda's silences by resisting the temptation to impose a meaning (deemed universal because legitimised) upon her experience. And the non-imposition of such universal meaning (or a diagnosis considered universal) implies the awareness of the structural violence implicit in the power position of the doctor (Farmer, 2004). The exercise of subtracting hegemonic culture from medical practice is basic to the new cross-cultural psychiatry. The proper attribution of a diagnostic feature to a foreign patient varies according to the patient's culture (Jadhav, 2009). In this sense, the same medical symptom can require opposite or different therapeutic strategies as a result of the different cultural meanings involved in the treatment of culturally different patients. Jadhav gives the example of expressed emotions among patients diagnosed with schizophrenia in India and the UK, and adds:

The past decade of research in medical anthropology and cultural psychiatry has continuously argued that the discipline of psychiatry might benefit from a fuller reexamination of its own cultural premise, rather than focus on how cultural variations in constructs such as Expressed Emotions in different societies could be better explained. (Jadhav, 2009, p. 95)

So the challenge is to self-reflect about the cultural premise of psychiatry in itself, and not only to try to take into account the culture of the other. 
This premise/conclusion is useful for the work of both psychiatrists and social scientists, as it allows us to acknowledge the extent to which the place from where we speak and ask our questions might be completely alien to our interlocutors. Likewise, the very language that we use might need an intercultural detour to get to a point of negotiation with the interlocutors. And a third dimension of the communication challenge between asymmetric object positions can be found in the inherited nature of the scenarios of interaction in official institutions (a medical consultation, an administrative interview at the Borders and Immigration Services of the State, at court and in a police department). Therefore, the possibility of inventing alternatives with a view to achieving possible dialogue requires the examination of: (1) the social status of each participant, (2) respective sites of locution and action and (3) history of the communicational setting.

\section{Memory and the embodied nature of object/subject positions}

Trying to understand the available means (diagnosis and incorporated knowledge) that we see at the same time preventing our interlocutors from speaking (through their hegemonic status) leads us into a whole new dimension of the 'duty to know' (devoirsavoir): the duty of memory. In addition to the historical memory of the broader contexts of colonialism and post-colonialism, implicit above or of women's condition in societies, authors such as Michel de Certeau (1988) and Derrida (1995) have suggested that memory is a private archive of collective history. Thus, it is material and cultural, even when it has been obliterated by forgetting or fragmentation. Each person's private archive is tangibly stored in his/her body, which is both the source and record of the deposit, presented in the form of impressions. Though it might not speak, sing or dance those impressions, each body transports the silences (whether imposed, guarded or carried voluntarily) of those same impressions. Thus, a tangible document of forgetting and obliteration may be encountered in the silences of our interlocutors. In the case of many undocumented immigrants, silence can be a passport to unique possibilities that open up on the margin of the law or in the gaps that exist in it.

In his work about the refugees in African camps (2011), Michel Agier analyses the situation of the refugee, and that of the foreigner, not as an identity but rather as a place. The territorial nature of this existential condition of the refugee corresponds to a political status of extra-territoriality and dependency that determines the terms and contents of possible communication with non-refugees. Agier posits his work as a fundamental critique of what he calls 'the partial globalisation' since foreigners, refugees and the exiled of our time are externalised (or internally marginalised) from a possible 'common world'. The same idea was suggested by Zygmunt Bauman in the late 1990s, when the Polish sociologist highlighted the fact that globalisation processes are promoted by globalizers in detriment of the globalised (Bauman, 1998). In this context, borders are no longer points of contact and exchange, but rather insurmountable barriers and walls of inequality, where the unforeseen foreigner becomes the object of 'managing the undesirables' (Agier, 2008). This is true in the Mediterranean Sea, as it is in the Mexican/ US border or the south-eastern European territorial border in Greece, or north-western French/British frontier (cf. Documentary Film 'The Wall' and fiction 'Welcome'). But a consequently metaphorical wall also exists in official communication happening in institutional settings, such as refugee centres, camps and general public services in host countries (cf. documentary film by Fernand Melgar, 'La Forteresse'), such as police departments, courts, medical consultations and schools. Here, we can observe a 'daily-life politics of silence' used by the refugees as a way to survive individual and collective 
memory. Jay Winter's idea of the life cycle of silence (Winter, 2010) may apply to such strategy in the sense that refugees in retention centres or camps live suspended lives in search of future solutions. So, there are times when only silence can speak, and times when, eventually, 'liberation' becomes possible. Jay Winter highlights, in this regard, that the fact of becoming capable of telling one's story makes people authors of their lives (Winter, 2010), which means that they become entitled and (literally) authorised, emancipated subjects. The stage for such emancipation cannot be found in the overdetermined institutional settings of the state for the reasons previously analysed.

Silences, amnesias and fragmentations are traces of that memory which also serves the function of mourning: mourning for the words that cannot be uttered, mourning for the stories that cannot be told and mourning for the amnesia of whoever has been deprived of their subjectivity and thus becomes alienated from themselves. These subjectivities have been rendered invisible through forgetting or historical obliteration. They deserve to be recognised, known and expressed in the tangible form of silences that are heard. Thus, by naming Fernanda's silences, like those of her interlocutors, as we have seen, acknowledging them as embodied, we can go some way towards curing the individual and collective amnesia that has underpinned them from the outset. As in Marlene NourbeSe Philip's (2008) work into the restoration of the memory and dignity of victims of slavery, here too the unspoken past re-enacted/revived in the transcultural consultation needs to be told and revisited. That is to say, there needs to be a testimony that gives account of silences so full of meaning.

In practical terms, this is also a question of language in general, and languages in particular: of those languages that we learn as our mother tongue or as a foreign one; of the languages in which we are versed and versatile and through which we position ourselves on the side of whoever can speak; of those that we have not 'mastered' and which therefore do not allow an equivalent positioning; and of languages that become confounded with the language of one's own subjectivity. In short, it concerns language, languages and speech as both power and empowerment (pouvoir-être) both in the polis and for oneself, in the good Western hypermodern manner in which we live, namely through new communications tools accessible to a growing number of people in all countries, and social classes (cell phones, Internet and social networks).

The work of restoring silences around Fernanda's case allows us to recognise the need to free ourselves from the rules and canons which ignore all that is uncertain. From the outset, these compromise the exercise of articulating forgetting, amnesia and invisible subjectivities which have ceased to exist or reveal themselves to the more attentive amongst us (belying appearances). This work has of course to be accompanied by a parallel effort at self-reflexivity on the part of hegemonic knowledge that tends to indulge in monologues, imposing pre-existing categories of understanding rather than trying to know more. Despite apparent methodological insignificance, the acts of listening to silence and paying attention to the contradiction between the doctor's diagnosis and the patient's behaviour become moments and sites of substantive production. They can teach us how to tell stories from the gaps in them. As such, this procedure offers not only a methodological and technical challenge but also an epistemological one.

In fact, there is a great deal of knowledge that can be produced from Fernanda's silences, concerning not only the distant historical context of the relationship between Portugal and its ex-colonies, but also the equally colonial history of the framework in which we met her - the psychiatric consultation - (Beneduce, 2009) and the situational contexts of her encounter with Portuguese institutions, her history as a former street-seller or hawker ${ }^{3}$ and her status in Portugal as a refugee with children living in different 
countries. This yields a civic conception of knowledge, which should enable us to escape the conventionalised bounds of how to conduct 'scientific' analyses or interviews in order to allow other meanings - less obvious ones - to emerge. Fernanda's silence did not seem to be a form of resistance in the conscious or political sense of someone who is able to speak but chooses not to do so. Instead, her resistance might be interpreted as the result of a violence and oppression that she experienced throughout her personal, family and generational history as a woman in a particular cultural context who migrated to another African country alone and later took refuge in a European country, the country that had once colonised her own.

Fernanda's silence is comparable to the hugs and kisses that do not fit into the psychiatrist's diagnosis: they resist classification, though did not have the power to question the knowledge of someone such as the doctor. In order for the hegemonic knowledge of medicine and mainstream social science to question itself, there is a need to develop a historical consciousness of the positions of power occupied by their everyday representatives (i.e. doctors and social scientists), as well as a (non-quotidian) capacity to tune into the instruments of knowledge that are our own bodies, beneath and beyond the imperative of macrocephalic rationality, or that which Derrida called the dogmatism of the paternal logos' (2000).

\section{Dialogic encounters in contexts of asymmetry: the framework of biographical research}

Biographical research plays an important role in exploring the plasticity of contexts of asymmetry in its fields of inquiry. As attested by the work of authors such as Franco Ferrarotti (1981), Gaston Pineau (1996) and the Geneva school in Adult Education, biographical research creates the times and spaces to emancipate 'identity narratives', and forge possible reciprocities among researchers and the researched. Ferrarotti (1981) defended the 'autonomy of the biographic method' in sociology, and pledged for the heuristic value of life stories, life narratives and oral history. He placed emphasis on the synthetic praxis of human actions (simultaneously, individual and collective and singular and historical), including speech, thoughts, dreams or aspirations. Drawing from Sartre's existentialism, the Italian sociologist defended the idea that the epistemological legitimacy of biography relies in a necessary shift from a monothetic logic of understanding social life towards an ideographic one. In this sense, life experiences translate social worlds and social worlds are translated by life experiences, stories and narratives, including silent ones. For the researcher to get to know the ideographic forms and contents of (social) life, there is the need to work from the standpoint of what Ferrarotti calls 'the clinical pole of sociology'. Consequently, it is a qualitative, intimate work of relation with concrete people in the field. In this sense, it deals necessarily with asymmetries and differences - sometimes, radical ones, like the ones analysed in this paper.

More recently, Christine Delory-Momberger (2004, 2006, 2009) and Jeanne-Marie Rugira (2008) developed theoretical and practical work about the use of life narratives and the role of the researcher in this work. These two scholars are important names in both fundamental research and action-research with life stories, biographical accounts, processes of biographisation, biographical workshops and sensitive listening. JeanneMarie Rugira (2008) questions the place of bodily relations and sensorial expression within research and training in the social sciences dealing with such tools and objects. She argues that the relationship with the body constitutes an incontestable pillar for the 
collective production of meaning and knowledge. It is that relationship that restores the capacity to learn, adapt and react in a way that transcends automatic socially conditioned responses. Biographical workshops orchestrated by Rugira, as well as by Josso (1991), and Delory-Momberger (2004) develop the skills of attention and perception in order to learn, understand and act within an experimental procedure used in phenomenologically inspired biographic research. More recently, we have developed a research project with immigrants in Portugal based on these workshops, where an attuned listening exercise introduces the participants to an experience of 'shared diversity', or communality in diversity, since each one experiences the same exercise in very different ways. A paper in Portuguese examines in detail the functioning and analytical dimensions of the workshops (Lechner, 2012).

Rugira quotes Simone Weil about the transition from attention to perception: 'Extreme attention is what constitutes man's creative faculty [...] The amount of creative genius in a period is rigorously proportional to the amount of extreme attention'. For Rugira, research, training and social intervention are creative enterprises that involve tracing pathways that open up new possibilities; meanings are unveiled in the process of learning how to perceive, reflect, dialogue and understand oneself, others and the world. The way each person perceives the world both depends upon and determines the experience that he or she has of it. For this, we have to train ourselves to see properly. Merely assessing or examining is not enough. It is necessary to learn through experience, not only with thought. Rugira says that we have to become "visionaries of our own activity', suspending mindless action and taking responsibility for enriching our own perceptions. We have to denounce crude representations of ourselves, others and worlds, and deplore our own incapacities in order to refine our approach to lived experience, learning to embody that which we know or wish to explain. This involves explaining what we know as experience through the practice of epoche, as both practice and attitude, within processes of research, learning and understanding.

However, Rugira also recognises that the human ability to explore its own experience is not spontaneous, that it is necessary to cultivate and train it if we want to do more than merely scratch the surface. Her theoretical and practical suggestions, which Lechner has had first-hand experience of as a trainee, ${ }^{4}$ become all the more relevant when we understand Rugira's personal and theoretical background. It is significant that she was originally from Rwanda and witnessed genocide, followed by exile in Canada, living far away from her children and husband and having to struggle to acquire Canadian nationality. From these traumatic experiences, she developed a privileged capacity to apprehend new perceptions of herself, others and the world (she had been a militant educator in her country of origin). In exile, the new perception of herself was a question of survival - as she describes in the below-cited article. Now it is a question of necessity. She says:

I learned to get in touch with subjective experience and understood myself as a subject. I noticed, with delight, that by experiencing an inner gesture and describing it with precision in a way that suspended ordinary cerebral activity, I was able to develop a richer sensorial response that enabled me to take body. (2008, p. 78, my italics)

For Rugira, the survivor of genocide, the body must be at the centre of our research projects. It is the sine qua non of our inhabited knowledge, and can give access to a form of empowerment (pouvoir-être), provided it is spoken, shared and divulged. 
Here we turn again to Fernanda's silences. Like those of all the other migrants who we can encounter in many different terrains, they teach us more about what an interview is and how we should position ourselves in that delicate work of listening. In the wake of this sensitive listening that hears the silences and lingers on them, the theoretical and practical work of biographical research, namely through biographical workshops, is interested also in the performative, mnemonic and political dimensions of life narratives. These workshops involve exercises in listening, autobiographical writing and sharing, through which participants can experience (if they want and are able to) the difference between sensitive listening and the kind of listening that has no time to look/feel the resonances and impressions because it has no pauses.

As a dimension of training in biographical research, biographical workshops offer a form of group work in which the situated nature of listening is laid bare (each participant interprets the same accounts in his/her own way) and where experiences are reported in all their diversity. As in an African 'word tree' (arbre à palabre), where the group sits around a baobab tree, thus providing each person with a unique perspective of that tree that is different from the others', here too each participant experiences a range of possible readings of the same object of contemplation (each account is read aloud). The biographical workshops also encourage the exchange of impressions about the autobiographical narratives of the other participants based on the resonances that they provoke in the body. Sensitive listening foregrounds a kind of listening that is anchored in the body of both researchers and the researched - and which attempts to develop a methodological vigilance to guard against rash judgements that are merely cognitive in nature. The act of knowing or trying to understand from this bodily awareness produces results that are substantially different from the act of knowing based on a head isolated from the trunk, limbs or gut.

But it requires courage to put this into practice in the context of ethnographic research or academic training. It requires a shift to a paradigm of knowledge that is based less on a belief in the objectivity of the objects of social studies and which is more secure about the changing, unstable and unpredictable nature of those same objects. It creates concrete challenges to the status of the parties involved in each research, bringing forth an anthropology of reciprocity (Temple, 2003). The fundamentals of such work are at the antipodes of hegemonic knowledge production and challenge ethnography in very practical terms: reciprocities, asymmetries and coauthorship.

At this point, we are reminded of Fernanda. Having survived other exiles - at the reception centre, in her family, in herself and in the country that received her as a refugee - she was finally exiled from herself, like so many other migrant women, who suffer in body and mind what words cannot express, what words only mask in the contradiction of wanting to speak silences, obliterations and the amnesias of history, which are collective and leave out the echoes of the cries of pain and affliction.

In fact, referring back to the original aim of this paper, we can say that silences and silencing in our ethnographic work reflected not only the confiscated voice of the patient but also that of the doctor and the anthropologist. Like the characters in a play on post-colonial encounters set in the context of contemporary south/north relations and migrations, all parties involved cohabited a shared historical inheritance but with fundamentally different discursive positions.

The position (material, symbolic and political) of the interlocutors is then decisive for understanding the meaning and forms of communication and dialogue in the reported case study, requiring a concomitant shift if the aim is to overcome the impossibility of dialogue. By escaping the monologue of the medical hegemonic knowledge, cross-cultural/ 
international psychiatry enables to create spaces of encounter and therapeutic strategies that help critically examine the patient-doctor relation, as well as their respective knowledge. In the same way, biographical research posits researchers and the researched in a kind of interaction that brings to the front the relational dimension of ethnographic work. The intrinsic relational nature of these interactions, in its turn, brings the possibility of communication and inter-knowledge. If 'all knowledge is inter-knowledge' (Sousa Santos, 2007), the advocacy of reason and truth in one sole subject position does not proceed. An ecology of knowledge is the epistemic way to go beyond abyssal thinking and colonial action over the other.

If we have to choose between a grotesque obedience to ways of thinking and doing research that fail to listen to the words not said, and the courage to write about silences that 'take body' in our fieldwork, it would seem more useful to opt for the latter. For it is there that the silences are in fact expressed. As Nourbese Philip says:

(Marlene NourbeSe Philip, 1989)

When silence is
Abdication of Word tongue ... and lip
Ashes of once in what was
.. Silence
Song Word Speech
Might I ... like Philomena ... sing
Continue
Over
Into
... pure utterance.

\section{Funding}

This research was funded by The Portuguese National Science Foundation (Fundação para a Ciência a Tecnologia). [grant number FCT/BPD/11548/2002], Instituto de Ciências Sociais da Universidade de Lisboa, [grant number FCT/BPD/26099/2005], CEAS/ISCTE, Lisbon, Portugal.

\section{Notes}

1. The transcultural consultation (Consulta do Migrante) at Miguel Bombarda was open to public in 2004 after the initiative of a small group of practitioners with experience with foreign patients or clinical settings. Namely, the founder director of this service had worked for several years in the Portuguese Hospital of Macau, until the transition of the territory Portuguese sovereignty to China.

2. Post-doc project granted by the Portuguese National Science Foundation which produced, among other scientific and academic outputs, an edited volume on 'Migrations, health and cultural diversity' (Migração, Saúde e Diversidade Cultural, ICS, Lisbon: 2009).

3. Hawkers are agents of a type of trade that economics dismisses as 'informal'. However, in Cape Verde, this type of activity forms an important axis of the transnational economic and cultural movements that traverse this island country of migrants and connect it to the world. It involves networks of men and (especially) women that operate at the (often silenced) margins of the economic and cultural hegemonies that make up today's globalised world (Marzia Grassi, ICS, 2003).

4. Biographical workshop (Atelier biographique), Univerity of Paris, June 2004.

\section{Notes on contributors}

Elsa Lechner, Ph.D. in social anthropology (Paris, 2003), is a principal investigator at the Center for Social Studies of the University of Coimbra where she coordinates a research project on 
collaborative research among immigrants in Portugal funded by the Portuguese National Science Foundation. She has conducted her doctoral research among Portuguese emigrants in France, and her Post-doc project at the Transcultural Consultations for Migrants in a Psychiatric Hospital in Lisbon (2004-2007). Currently, she is a Fulbright Scholar in the USA conducting an exploratory study about the Portuguese in Newark, New Jersey, hosted by Brown and Rutgers Universities.

Olga Solovova, Ph.D. in sociolinguistics (Coimbra, 2014), is a researcher at the Centre for Social Studies in the Humanities, Migrations and Peace Studies Group. She is a member of the project implementing collaborative research among immigrants in Portugal, and of a European project on learning languages online e-learning. Her Ph.D. thesis examines policies of language-in-education that sustain the existence of complementary schools for Eastern European immigrant children in Portugal. Her research interests include language ideologies and policies, discursive construction of cultural identity in multilingual societies as well as multilingual and biliterate literacy practices.

\section{References}

Agier, M. (2008). Gérer les indésirables. Des camps de réfugiés au gouvernement humanitaire [Managing the undesirables. Refugee camps and humanitarian government]. Paris: Flammarion.

Agier, M. (2011). Le couloir des exilés. Être étranger dans un monde commun [Corridors of exile: A worldwide web of camps by Michel Agier]. (E. Rosencrantz, Trans.). Bellecombe-en-Bauge: éditions du Croquant.

Andersen, T. (2007). Human participating: human 'being' is the step for human 'becoming' in the next step. In H. Anderson \& D. Gehart (Eds.), Collaborative therapy: Relationships and conversations that make a difference (pp. 81-95). New York, NY: Routledge/Taylor \& Francis.

Ashcroft, B., Griffiths, G., \& Tiffin, H. (1995). The post-colonial studies reader. London: Routledge.

Bahktin, M. (1981). The dialogic imagination. Austin: The University of Texas Press.

Bailey, A. (1998). Privilege: Expanding on Marilyn Fry's oppression. Journal of Social Philosophy, 29(3), 104-119.

Barker, P., \& Stevenson, C. (Eds.). (2000). Construction of power and authority in psychiatry. Oxford: Butterworth-Heinemann.

Bauman, Z. (1998). Globalization: The human consequences. New York, NY: Columbia University Press.

Beneduce, R. (1998). Frontiere dell'identità e della memoria. Etnopsiquiatria e migrazioni in un mondo creolo [Frontiers of identity and memory. Ethnopsychiatry and migrations in a creole world]. Milan: Franco Angeli.

Beneduce, R. (2009). Etnopsiquiatria e migração: a produção histórica e cultural do sofrimento [Ethnopsy chiatry and migration:The historical and cultural production of suffering]. In Elsa Lechner (org.), Migração, saúde e diversidade cultural [Migration, health, and cultural diversity]. Lisboa: Imprensa de Ciências Sociais.

Bhabha, H. (1983). The other question ... Homi K. Bhabha reconsiders the stereotype and colonial discourse. Screen, 24(6), 18-36. doi:10.1093/screen/24.6.18

Caruth, C. (1996). Unclaimed experience. Trauma, narrative, and history. Baltimore: John Hopkins University Press.

Comelles, J. M. (2013). De la locura como exceso a la locura como enfermedad [From madness as an excess to madness as illness]. In D. S. Lorda, C. G. Rodriguez, \& A. C. Vasquez y Olga Villasante (Eds.), Razón, locura y sociedad. Una mirada a la historia desde el siglo XXI [Reason, madness and society: A glance to history in the 21st century] (pp. 143-163). Madrid: Asociación Española de Neuropsiquiatria, Estudios, 51.

De Certeau, M. (1988). L'Écriture de l'Histoire [The writing of history]. New York, NY: Columbia University Press.

Delory-Momberger, C. (2004). Les Histoires de Vie : de l'invention de soi au projet de formation [Life stories: From the invention of oneself to educational project] (2nd éd.). Paris: Anthropos.

Delory-Momberger, C. (2006). Les ateliers biographiques de projet [Formation and socalization: The project biographical workshops]. Educação e Pesquisa, 32(2), 359-371. São Paulo.

Delory-Momberger, C. (2009). La Condition Biographique; Essais Sur Le Récit De Soi Dans La Modernité Avancée [The biographical condition: Essais on self-narrative in advanced modernity]. Paris: Téraèdre. 
Delory-Momberger, C. (2012). La langue coupée. Quand le récit doit faire preuve [Tongue cut. When the story must prove]. In A. Brossat \& M. Déotte (Dir.), Corps subalternes: Migrations, expériences, récits (pp. 159-172). Paris: L'Harmattan.

Derrida, J. (1995). Mal d'Archive : une impression freudienne [Archive fever: A freudian impression] (E. Prenowitz, Trans.). Paris: Galilée.

Derrida, J. (2000). Of hospitality. Stanford: Stanford University Press.

Fanon, F. (1952). Peau noire, masques blancs [Black skin, white masks]. Paris: Seuil.

Fanon, F. (1961). Les Damnés de la Terre [The wretched of the earth]. Paris: François Maspero.

Farmer, P. (2004). An anthropology of structural violence. Current Anthropology, 45, 303-325. doi: $10.1086 / 382250$

Fernando, S. (2003). Cultural diversity, mental health, and psychiatry: The struggle against racism. Hove: Brunner-Routledge.

Ferrarotti, F. (1981). Epistemological and methodological issues - On the autonomy of the biographical method. In D. Bertaux (Ed.), Biography and society. The life history approach in the social sciences (pp. 19-29). London and Beverly Hills: Sage.

Giordano, C. (2008). Practices of translation and the making of migrant subjectivities in Contemporary Italy. American Ethnologist, 35, 588-606. doi:10.1111/j.1548-1425.2008. 00100.x

Grassi, M. (2003). Rabidantes. Lisbon: ICS.

Harding, S. (1995). Subjectivity, experience and knowledge: An epistemology for rainbow coalition politics. In J. Roof \& R. Wiegman (Eds.), Who can speak?: Authority and critical identity. Chicago: University of Illinois Press.

Jadhav, S. (2009). What is cultural validity and why is it ignored? The case of expressed emotions research in South Asia. In S. van der Geest \& M. Tankink (Eds.), Theory and action: Essays for an anthropologist (pp. 92-96). Amsterdam: AMB.

Jaworski, A. (1993). The power of silence: Social and pragmatic perspectives. Newbury Park, CA: Sage.

Josso, M.-C. (1991). Cheminer vers soi [Walking towards oneself]. Paris: L'age d'homme.

Kirmayer, L. (2000). The future of cultural psychiatry: An international perspective. Canadian Journal of Psychiatry, 45, 438-446.

Kirmayer, L. (2001). Cultural variations in the clinical presentation of depression and anxiety: Implications for diagnosis and treatment. Journal of Clinical Psychiatry, 62, 22-30.

Kleinman, A. (1980). Patients and healers in the context of culture: An exploration of the borderland between anthropology, medicine, and psychiatry. Berkeley: University of California Press.

Kleinman, A. (1985). Culture and depression: Studies in the anthropology and cross-cultural psychiatry of affect and disorder. (A. Kleinman \& B. Good, Eds.). Berkeley and Los Angeles: University of California Press.

Kleinman, A. (1995). Writing at the margin: Discourse between anthropology and medicine. Berkeley and Los Angeles: University of California Press.

Laacher, S. (2007). Le peuple des clandestins [The clandestine people]. Paris: Calmann-Lévy.

Laacher, S. (2009). Mythologie du sans-papier [Mythology of the irregular migrant]. Paris: Le Cavalieu Bleu.

Lemke, J. (2008). Identity, development and desire: Critical questions. In C. Caldas-Coulthard \& R. Iedema (Eds.), Identity trouble. Critical discourse and contested identities (pp. 17-41). Basingstoke, NY: Palgrave Macmillan.

Lechner, E. (2012). Oficinas de trabalho biográfico: pesquisa, pedagogia e ecologia de saberes [Biographical workshops: Research, pedagogy, and ecology of knowledge]. Revista Educação e Realidade, 37(1), 71-87.

Littlewood, R. (1990). From categories to contexts: A decade of the 'new cross-cultural psychiatry'. British Journal of Psychiatry, 156, 308-327. doi:10.1192/bjp.156.3.308

Littlewood, R. (2006). Aliens and alienists: Ethnic minorities and psychiatry. London: Taylor \& Francis.

Moro, M.-R. (2005). Avicenne l'andalouse: Devenir thérapeute en situation transculturelle [Avicenne the Andalusian: Becoming a therapist in a transcultural situation]. Paris: la Pensée Sauvage.

NourbeSe Philip, M. (1989). She tries her tongue: Her silence softly breaks. Charlotte Town: Ragweed Press.

NourbeSe Philip, M. (2008). Zong! Middletown, CT: Wesleyan University Press. 
Pandolfo, S. (1997). Impasse of the angels. Scenes from a Moroccan space of memory. Chicago: Chicago University Press.

Pease, B. (2006). Encouraging critical reflections on privilege in social work and the Human Services. Practice Reflexions, 1(1), 15-26.

Pineau, G. (1996). Les histoires de vie comme art formateur de l'existence [Life stories, a formative art of the being]. Pratiques de formation, (31), 65-80.

Portes, A. (2011). Tensions that make a difference: Institutions, interests, and the immigrant drive. Sociological Forum, 27, 563-589. doi:10.1111/j.1573-7861.2012.01335.x

Rousseau, C. (2002). Incertitude et clinique transculturelle [Uncertainty and transcultural clinical practice]. L'Évolution psychiatrique, 67, 764-774. doi:10.1016/S0014-3855(02)00168-8

Rousseau, C., Gauthier, M.-F., Lacroix, L., Benoît, M., Moran, A., Rojas, M. V., \& Bourassa, D. (2006). Du jeu des identités à la transformation de réalités partagées: Un programme d'ateliers d'expression théâtrale pour adolescents immigrants et réfugiés. Santé mentale au Québec, XXXI (2), 135-152.

Rugira, J.-M. (2008). A relação com o corpo e com a sensorialidade na história de vida: por uma abordagem somatopedagógica [Body and sensoriality in the life histories approach: Towards a somatopedagogy]. In Maria da Conceição Passeggi (Ed.), Tendências da pesquisa (auto) biográfica [Tendencies of (auto)biographical research] (pp. 73-93). São Paulo: Paulus.

Scarry, E. (1985). The body in pain. The making and unmaking of the world. New York: Oxford University Press.

Scott, J. (1985). Weapons of the weak: Everyday forms of peasant resistance. New Haven, CT: Yale University Press.

Seikkula, J., \& Olson, M. E. (2003). The open dialogue approach to acute psychosis: Its poetics and micropolitics. Family Process, 42(Fall), 403-418. doi:10.1111/j.1545-5300.2003.00403.x

Seikkula, J., Alakare, B., Aaltonen, J., Holma, J., Rasinkangas, A., \& Lehtinen, V. (2003). Open dialogue approach: Treatment principles and preliminary results of a two- year follow-up on first episode schizophrenia. Ethical and Human Sciences and Services, 5, 163-182.

Sousa Santos, B. (2007). Beyond abyssal thinking. From Global lines to ecologies of knowledges. Review, $X X X(1), 45-80$.

Spivak, G. (1988). Can the subaltern speak? In C. Nelson and L. Grossberg (Eds.), Marxism and the interpretation of culture (pp. 66-111). London: Macmillan.

Temple, D. (2003). Teoría de la reciprocidad [Theory of reciprocity] (3 volumes). La Paz: Padep-Gtz.

Wagner, R. (2012). Silence as resistance before the subject, or could the subaltern remain silent? Theory, Culture and Society, 29(6), 99-124. doi:10.1177/0263276412438593

Winter, J. (2010). Thinking about silence. In E. Ben-Ze'ev, R. Ginio, \& J. Winter (Eds.), Shadows of war. A social history of silence in the twentieth century (1st ed., pp. 3-31). Cambridge: Cambridge University Press. 